\title{
Social solidarity movement to prevent the spread of COVID-19 pandemic in Indonesia
}

\section{Gerakan solidaritas sosial untuk mencegah penyebaran pandemi COVID-19 di Indonesia}

\author{
Munadhil Abdul Muqsith ${ }^{*}$, Rizky Ridho Pratomo², Ana Kuswanti², \& Valerii \\ Leonidovich Muzykant ${ }^{1}$ \\ 'Peoples' Friendship University of Russia (RUDN University), Moscow, Russia \\ ${ }^{2}$ Department of Communication Science, Faculty of Social and Political Sciences, \\ Universitas Pembangunan Nasional Veteran Jakarta \\ Address: ${ }^{1}$ Jalan RS Fatmawati Raya, Depok, West Java, Indonesia 2450 \\ ${ }^{2}$ Ulitsa Miklukho-Maklaya 6, Moscow, Russia 117198 \\ E-mail:munadhil@upnvj.ac.id
}

Article History: Received 28 July 2020; Accepted 10 March 2021; Published Online 19 April 2021

\begin{abstract}
The COVID-19 pandemic has affected many sectors, especially the health and economic aspects. On the bright side, the potential for social solidarity in the community has been increased. New media technology becomes an oasis in the midst of anxiety when people are forced to distance themselves or carrying out social distancing. Net citizens are using new media technology to raise solidarity and appeal to prevent the spread of COVID-19 from various campaigns on social media. This research aimed to study social movements to prevent the spread of COVID-19 and employed a qualitative approach using content analysis. The results showed that the pandemic triggered the public to take advantage of various social media platforms by creating content about public education and campaigning to raise funds or crowdfunding. It is as if a blessing in disguise when this disaster resulted in the value of collaborative work or gotong royong that comes from Pancasila, which characterizes the nation's values so that people are motivated to remind each other to maintain health and also help others to ease the burden of those affected. The solidarity movement to prevent the spread of the COVID-19 pandemic is dominated by public figures.
\end{abstract}

Keywords: COVID-19 pandemic; new media; social solidarity

\begin{abstract}
Abstrak
Pandemic COVID-19 berdampak pada banyak sektor, terutama kesehatan dan ekonomi. Sisi baiknya, tercipta potensi solidaritas sosial di masyarakat saat pandemi COVID-19 menyerang seluruh penduduk bumi, termasuk Indonesia. Teknologi media baru menjadi oase di tengah kegundahan, saat manusia dipaksa menjaga jarak atau melakukan pembatasan sosial. Teknologi media baru dimanfaatkan oleh warga net untuk menggalang solidaritas dan imbauan untuk mencegah penyebaran COVID-19 melalui media sosial. Tujuan penelitian ini adalah mengkaji gerakan sosial guna mencegah penyebaran COVID-19. Studi ini dilakukan dengan metode kualitatif menggunakan analisis konten. Hasil penelitian menunjukkan bahwa pandemi COVID-19 memicu masyarakat memanfaatkan berbagai platform media sosial dengan membuat konten tentang edukasi masyarakat dan kampanye menggalang dana. Seolah-olah berkah terselubung saat bencana ini melahirkan nilai gotong royong yang berasal dari Pancasila, yang menjadi ciri nilai bangsa, sehingga masyarakat termotivasi untuk saling mengingatkan untuk menjaga kesehatan dan membantu masyarakat untuk meringankan beban yang terkena dampak. Gerakan solidaritas untuk mencegah penyebaran pandemi COVID-19 ini didominasi oleh publik figur.
\end{abstract}

Kata kunci: pandemi COVID-19; media baru; solidaritas sosial

\section{Introduction}

President Jokowi announced that two Indonesian citizens were affected by COVID-19 on 2 March 2020 (Ihsanuddin 2020). Nine days later, World Health Organization (WHO) declared the increase in COVID-19 to be a pandemic, and instantly, the public panicked. The price of basic needs surged due to panic buying, which resulted in the scarcity of basic needs in the market. Besides, masks and hand 
sanitizers were out of stock instantly. This phenomenon caused the price of masks and hand sanitizers to skyrocket in both offline and online markets because these two objects serve as self-defense tools to prevent COVID-19 from entering the human body. This situation occurred due to excessive community phobia toward the COVID-19 pandemic. There was the extreme phobia of people infected with the coronavirus, such as in Wuhan, China, while another phenomenon that added to public panic was the spread of misinformation and disinformation about the coronavirus.

The Indonesian government then issued a social distancing policy or a Large-scale Social Restriction Policy or Pembatasan Sosial Berskala Besar (PSBB). Restrictions on community activities for two weeks were enacted. Car-free days at MH Thamrin and Jalan Sudirman, Jakarta, were suspended, worship activities were restricted, educational institutions were closed, and offices were also asked to be closed or known as work from home (Amindoni 2020). In the grim and fearful situation, there was a feeling of shared common goals that must be fought together in various walks of life so that they united against COVID-19. The community moved to remind one another of the importance of clean and healthy living. In addition, social solidarity among residents emerged to reduce the economic burden, especially for most poor people who were directly affected by the pandemic. Besides, the community also showed solidarity with health workers who were at the forefront of handling COVID-19.

In the conditions of the COVID-19 pandemic, we must be grateful for the development of technology and communication media. The new communication media is a blessing in disguise because they can carry out various online-based social movements, primarily through social media. Social media exists in many different forms, including social networks, internet forums, weblogs, social blogs, microblogs, wikis, podcasts, images, videos, ratings, and social bookmarking (Zahri et al. 2019). The use of social media depends on the preferences of each party. Priliantini and Damayanti's (2018) research revealed how action solidarity groups for 411 and 212 preferred WhatsApp over Facebook because they were freer to spread information. After all, the groups formed were based on equal values and were considered more personal. Priliantini and Damayanti's (2018) study emphasized how social media becomes a new medium to interact and provide information quickly, and it can illustrate how social media's potential can be a tool to mobilize social solidarity.

The study of Bao et al. (2020) also mentioned that social media has an important role in building social solidarity to increase trust, reduce chaos, educate people, and reduce medical burdens. Social media is used not only as a means of communication but also as a media to campaign vigilance against virus transmission. With social media, the public can invite other people to do things such as a movement to use masks and wash their hands, avoid crowds, even donate to medical personnel and people infected with the coronavirus.

In facing the COVID-19 pandemic, social solidarity has been created among the community in terms of helping out. The study of Bin-Nashwan et al. (2002) showed that the form of social solidarity in the face of a pandemic outbreak is mostly given to vulnerable groups such as workers, quarantine facilities, health centers, and medical personnel. These groups have a high risk of transmission and death due to the coronavirus. On the other hand, forms of social solidarity such as stay-at-home movements and donations are very helpful to those who are most in need. Previous studies have stated that social solidarity is the main weapon in fighting COVID-19 by promoting movement and empowering communities (Arora et al. 2020, Meinzen-Dick 2020, Valeriani et al. 2020). With the social solidarity movement, many people have been helped from the impact of the pandemic which has weakened many sectors.

The study of Smythe et al. (2021) found that in Canada, a form of social solidarity was carried out in the field of education where education was badly affected by the pandemic. This solidarity is very useful for helping teachers and students carry out teaching and learning activities. During a pandemic, learning takes place online. However, online learning experiences various obstacles, one of which is that students are stressed because there is no direct guidance from the teacher. Meanwhile, other previous studies stated that a common form of social solidarity was a campaign using masks and washing hands as a form 
of social care (Cheng et al. 2020, Szczesniak et al. 2020, Gunasekaran et al. 2020). The use of masks and the handwashing movement are massive social movements campaigned to fight against the COVID-19 pandemic. The public realizes that if everyone cares about health, social solidarity will arise so that they invite other people to care about the dangers of the coronavirus.

Emile Durkheim, a thinker who introduced solidarity, divided the concept into mechanical solidarity and organic solidarity. Mechanical solidarity is defined as a person bound in the form of solidarity with the same and robust collective consciousness (Zahri et al. 2019). This solidarity was rife in pre-industrial societies. Meanwhile, organic solidarity arises because of the division of labor and specialization, giving rise to dependence. Industrial society has this kind of solidarity. There is a clear difference between mechanical and organic solidarities. While mechanical solidarity comes from coercion, applies throughout pre-modernity, in modernity, it must increasingly give way to a more individualistic form of solidarity, which is organic solidarity, which is fed by complementary differences and interdependencies (Thijssen 2012).

The advanced Indonesian society has long had a tradition of collaborative work or (hereafter called gotong-royong) based on Pancasila, and it has been 75 years since Indonesia became an independent country. The value of gotong-royong has started to decline; however, it still resonates and exists in society, especially in rural communities and small circles. Activities that unite the local community through gotong-royong are still running well, such as during natural disasters, deaths, and many other activities that support the community in living in peace in diversity (Derung 2019). Therefore, this research aimed to elaborate on social movements to prevent the spread of COVID-19.

\section{Research Method}

This study employed a qualitative method using content analysis; the definition of content analysis is a research method that provides a systematic and objective means to make valid inferences from verbal, visual, or written data to describe and quantify specific phenomena (Wamboldt 1992). As a research technique, the content analysis provides new insights, increases a researcher's understanding of particular phenomena, or informs practical actions (Krippendorff 2003). The qualitative content analysis examines the relationship between the text and its likely audience meaning, recognizing that media texts are polysemic, for example, open to multiple meanings to different readers and tries to determine the likely meaning of texts to audiences (MacNamara 2005). The aim is to attain a condensed and broad description of the phenomenon, and the outcome of the analysis is concepts or categories describing the phenomenon (Elo \& Kynga 2007).

This study was a descriptive analysis that provided education and understanding to the reader, and the type of data used in this study was secondary data during March 2020. The researchers discussed how the pandemic had triggered many social movements from Indonesian people. The researchers examined the forms of movements from various media such as Instagram, mainstream media, Twitter, and Facebook. To improve and enrich understanding of social movements, the researchers also conducted literature reviews.

\section{Results and Discussion}

In the context of preventing COVID-19, the government is appealing and implementing a policy of "stay at home," which means to stay at home during a virus pandemic or at least carry out a personal quarantine at home for at least 14-days. The stay-at-home campaign also aims to minimize outside activities. This appeal applies to schools, universities, and the business world; however, the government is late to the implemented policy as COVID-19 has impacted Indonesia's economy. While many countries began to suspend flights to China, Indonesia's government was still passive about COVID-19; instead, the government massively promoted tourism and claimed that Indonesia is COVID-19 free. This decision has contributed profoundly to the degree of COVID-19 penetration in Indonesia. 
The incubation period of COVID-19, which is the time between exposure to the virus and symptom onset, is on average 5-6 days, but can be as long as 14 days (Lauer et al. 2020). The public is strongly advised to comply with these regulations and not leave the house if it is not essential. Participation from all parties is needed to reduce the rate of global spread. The campaign against COVID-19 is increasingly massive. As a result, many people are ultimately forced to stay at home not become infected. This pandemic, which has taken so many lives and caused fear, has stopped community activities. Furthermore, countless sacrifices were made by many parties to ensure the virus did not spread.

A lot of sympathy and appreciation has arisen, even leading some to do social movements to ease tensions and fundraising. Therefore, when COVID-19 attacked Indonesia, the resulted impact was profound, especially in the economy. Large-scale Social Restriction policy hindered much activity, particularly in economics. Companies and other businesses have struggled to adapt to the current situation, and they force to reduce employees or lay off employees to save on their expenses. According to the Ministry of Labour, 1.5 million people lost their jobs, 10\% were laid off, and 90\% were laid off; their status showed that the formal sector laid off was 160,067 workers from 24,225 companies and of 1,080,765 workers from 27,340 companies, while the informal sector was 265.881 workers from 30.466 companies (Sembiring 2020).

COVID-19 does not only affect workers, but also health workers who are fighting on the frontline. The massive increase in COVID-19 cases has made hospitals assemble all their resources. Not infrequently, they also run out of Personal Protective Equipment (PPE) to protect themselves from exposure to COVID-19. As a result, health workers lack PPE and are at high risk of being exposed to COVID-19. PPE in Tasikmalaya, West Java, for example, had only enough for three days, while the regional public hospital of Ciamis said their stock would run out within one week (Setiawan 2020). With the government being slow to implement effective policy, which worsened the condition, many people started rallying for social solidarity. This solidarity emerged as a result of the dire situation faced by society. Therefore, this pandemic then resulted in social solidarity, as described by Emile Durkheim that in times of instability, people can be moved to work together to help others and share responsibility so that the situation in society returns to stability. This global disaster caused emerging awareness and a system of solidarity among citizens. In Indonesia's context, there is a shared understanding and mutual feeling that "we" as Indonesian people must help each other to survive. Furthermore, helping each other is in Indonesian people's traits, which we know as gotong-royong. The existence of various social movements between citizens to be more concerned and share regardless of ethnicity, language, and the economy creates a spirit of cooperation.

Information and communication technology has become a bridge to connect many individuals to take action in solidarity. In this COVID-19 outbreak, many residents could not leave the house out of fear or maintain their health to be affected by a COVID-19; however, they do not need to meet face-to-face because technology compensates for its social media platforms such as Twitter, Facebook, Instagram, and WhatsApp. Moreover, the number of social media users in Indonesia is quite large. The researchers divided the two parts of social solidarity action through online media campaigns into material solidarity and immaterial social movements. Unfortunately, this online solidarity movement has become ineffective or empty because this movement is limited to mere ceremonial solidarity or from the bottom up. Simultaneously, the government seems confused in anticipating this virus attack so that there is no correlation between the community's solidarity and the government's handling. Meanwhile, there are more victims, both in terms of health and economy, which continue to increase day by day. This spirit of social solidarity must be maintained until COVID-19 can be overcome through the discovery of anti-viruses.

\section{Emerging of social movements in Indonesia}

COVID-19 has caused a broad impact on society, especially in the economy. Many people have lost their jobs as a result of the economic downturn. Informal workers are also one of the parties affected, and they cannot do selling activity because of social distancing policies. Consequently, they do not earn income; 
besides that, health is also affected, especially health workers, because those who handle COVID-19 are on the frontline. Much news has emerged that health workers lack personal protective equipment, starting to claim lives. The phenomena triggered public awareness, and people were moved to initiate social movements. One of them was a fundraising platform, Kitabisa.com, which created a campaign to help those who needed help. They carried the theme "Indonesia against Corona" with the hashtag \#BersamaLawanCorona in their campaign. It was done because parties other than the government can also assist in various ways.

On its official website, Kitabisa.com (2020) opened the donation by writing several narratives stated:

"The spread of the Coronavirus in Indonesia continues to expand. The impact of this virus is very worrying: Thousands of people are positive and under surveillance, while hundreds of others have died. These figures are not mere statistics, but concern the lives and lives of many people."

We can try to engage people's empathy by mentioning facts in the field; however, the phrase "these numbers are not mere statistics, however, concerns the lives of many people" described a disturbing situation. Moreover, in talking about the life that was taken away, people would be moved to be deeply involved in social movements. Then, the narrative on the official website of Kitabisa.com continued, stated:

"We cannot stand by watching the spread of this virus. We must help to stop the spread of the corona virus as quickly as possible. Through this fundraising, you and everyone can donate to help stop the spread of the corona virus."

This invitation was addressed to all communities and personalized. This personalization aimed to make us feel empowered and have the strength to help others and attracted empathy in humans. This action was taken responded to by 50,073 people, and they worked together to donate to help each other. The funds achieved had almost reached the target, approximately 4.3 billion IDR from 5 billion IDR. The amount would still increase because there were still 21 days before the fundraising auction was closed.

The target beneficiaries were comprehensive; low-income families, health workers at referral hospitals, UI Medical Chemistry students making hand sanitizers, people who wanted to check their COVID-19 status, and disinfectant kits in public spaces. Kitabisa.com also raised funds, this time aimed at informal workers, and this assistance will be used to buy basic materials so that their daily needs are met, and they do not need to leave the house to make a living amid the COVID-19 situation. This assistance will be distributed to several regions such as Jakarta, Bogor, Depok, Tangerang, Bekasi, Banten, Yogyakarta, East Java, West Java, and Central Java. In addition, they are also raising funds for medical personnel to be able to get food. Medical personnel does not have time to buy lunch because of the large number of patients treated.

Besides Kitabisa.com, other people raised donations to help those in need. These acts came from an Indonesian influencer, Rachel Vennya (2020), and she raised donations through Kitabisa.com. In the platform, Vennya used a different approach from Kitabisa.com. She stated: “...for example, a mother who is a nurse or a health worker at a referral hospital, they have to treat a positive patient with COVID-19. They have high occupational risks to protect us all."

Vennya took a motherly approach; when adjusted to a personal context, Vennya was a mother of two children (Awalia 2020). Hence, the motive was more personal than ours; the narrative of Vennya continued, stated: "...for example, a single parent who trades in the market to meet their daily needs. They cannot work from home and must earn a living."

Vennya invited people to imagine a mother's struggles, especially those who care for their children. Implicitly, Vennya tried to invite us to imagine, for example, our mothers struggling to keep earning a living, and this narrative will cause a sense of compassion in our hearts. 
Other parties who had participated in the COVID-19 social movement were Najwa Shihab through various platforms: website (www.narasi.tv), YouTube account of Narasi, YouTube account of Najwa Shihab, and live Instagram account of @narasi.tv. The fundraising was held on 25-28 March 2020 and received up to nine billion IDR through the Kitabisa.com platform. Najwa Shihab, through Narasi TV, engaged Twitter users in their social movements. Narasi TV provided visual records that people could use to listen to their points of view and empathized with their conditions. Najwa Shihab, the co-founder of Narasi TV, hoped that the donations collected could be helpful and multiply through five programs (\#BisaMakan, \#BisaSteril, \# Sembako14Day, \#RantangHati, and \#learning home).

Indonesian singer Tulus opened the \#dirumahaja (stay-at-home) music concert on 28 March 2020, and many Indonesian musicians participated in this event. The old singer Iwan Fals invited us to continue to grow stronger from home, and he hoped that we can still get beautiful things in this tense atmosphere and invited us to build strength and stay productive at home. In addition, a young Indonesian musician Afgansyah Reza said that he was proud because the community could help each other; he expressed his gratitude to those who contributed and invited to increase social solidarity to help all who struggled, especially medical workers.

Some names that were part of the \#DiRumahAja music concert were Andmesh, Anji, Armand Maulana, Fourtwnty, Hivi, Judika, Ridho Hafiedz \& Kaka, Eva Celia, Tulus, Rossa, Afgansyah, Vidi Aldiano, Gamaliel, Hindia, Ariel Noah, Yura Yunita, Kunto Aji, Barasuara, Raisa, Ardhito Pramono, Rendy Pandugo, Petra Sihombing, Ari Lasso, Iwan Fals, Trio Lestari and Didi Kempot. Furthermore, comedians Pandji Pragiwaksono and Bintang Emon also helped entertain the audience. In addition, politicians and state officials were also involved, including the former Vice President (Jusuf Kalla), Minister of StateOwned Enterprises (Erick Thohir), and Minister of Education and Culture (Nadiem Makarim).

Companies and media organizations also took part to help Indonesia's effort to tackle COVID-19. Gusdurian, a community that engages in Gusdur philosophy, participated in campaign actions to fight COVID-19. This movement's initiator was Mizan Group CEO (Haidar Bagir), with Alissa Wahid, the former president's daughter (Abdurrahman Wahid or Gusdur). With the hashtag \#salingjaga, Gusdurian invited people to share a little of their sustenance to help workers who were forced to work due to economic demands; thus, they were prone to exposure to the COVID-19. Proceeds from the fundraising would be distributed to people who could not afford it. Many parties, including artists, were involved in the \#salinjaga campaign, such as Ernest Prakasa, Endy Arifin, and Adhisty Zara. One of Indonesia's young artists, Zara, admitted that she was encouraged to join this movement. Zara applauded this movement because many people did not think about themselves and helped one another, and one Indonesian actor also admitted to being inspired by this activity.

In addition to material, the call for "DiRumahAja" flowed from several public figures and celebrities in the country. Following government and WHO regulations to stop the more massive spread of COVID-19, which was inviting people to do activities at home, some campaigns which later went viral and gained much public attention included a comedian, Bintang Emon. This stand-up comedian called for a funny invitation to the Singapore Straits Times because he was deemed able to socialize the appeal through social media to stay at home during the social distancing period to suppress the COVID-19 curve. The message conveyed by Emon was quite striking and it was given through a short video of approximately two minutes through Instagram. He invited the public to stay at home for a variety of reasons, which stated:

\footnotetext{
"Just stay at home first. We can go on holiday later. It's just fine if we don't go to the mall now, the mall will not turn into a canteen. It will be also fine if we don't go to the top of the mountain now, the top of the mountain will not turn to be short; we will have to keep climbing as well when we go there. Let's be together against Corona."
} 
Emon looked stern in his Instagram post, and he did not want people to keep going to the top of the mountain or the mall as this will exacerbate cases of the spread of COVID-19. Moreover, his assertiveness showed that there were moral obligations that must be fulfilled as an influencer because he had quite a lot of followers on Instagram, so he could convey his appeal to many people.

Moreover, artists, media, public figures, companies, and soccer players also contributed to the prevention of COVID-19. It is done on the official Twitter account of the Persija Jakarta football club@Persija_Jkt. Some of the club players, including Evan Dimas, Ryuji Utomo, Rico Simanjuntak, Marco Motta, Dutra Otavio, Andritany Ardhiyasa, Osvaldo Haay, and Rohit Chand, making \#TetapGerakdiRumah (keepmoving-at-home) video campaigns. This campaign aimed to enable people to do activities at home, following government recommendations. They carried and shared tips on how to prevent the spread of COVID-19 through their respective Instagram accounts. This campaign wanted to encourage and invited the community to stay home and kept on with their activities there. Small steps that could be taken to avoid the increasing number of victims exposed to COVID-19 were staying at home.

\section{The downside of the internet-based social movement}

The pandemic triggered people's movements to assist people in need, and the movement was varied, consisted of material assistance and information sharing through creative ways. Although social distancing had halted many activities, the internet had given people momentum to do something to suppress the COVID-19 impact. Considering that there were many social media users in Indonesia, it could help move people; as such, solidarity arose via the internet as a medium.

Steward and Schulze (2019) argued that three elements form solidarity: 1) motivation to take action on behalf of the group, and which is held individually 2) normatively, and 3) emotionally motivated readiness to support others in the group. In this case, the researchers argued that what formed solidarity in Indonesia was the motivation and norms or core values that underlay it all. New media based on the internet and technology had become a platform that facilitated social actions. Dolata and Schrape (2016) argued that the form of collective behavior outlined originates and develops, as seen, without any conditions. However, the presence of social and technical infrastructure enables the emergence of similarly oriented individual actions and the resulting collective behavior and which coordinates, guiding, monitoring, and, to some extent, controlling such collective activities.

Three motivations are underlying various social solidarity actions, and the first motivation is inviting. Inviting is intended to increase awareness so that people do not go out unless it is essential, such as buying staple goods. The campaigns carried out aimed to keep the community clean, and COVID-19 did not infect them. The ultimate goal was for the community to comply with the Government's call for activities at home.

The second motivation is to suppress the spread of hoaxes. According to the Ministry of Communication and Informatics, towards the end of April 2020 the number of reports related to COVID-19 hoaxes reached 600 people, with topics such as Gibran Rakabuming Raka's statement regarding the distribution of social assistance, the spread of the corona virus, and fake news from abroad (Annur 2020). Hoax news in the current pandemic situation is very threatening. It might lead to the acquisition of beliefs about the world, which directly reflected their contents; when this happened, individuals could misinterpret trust in reputable sources or general knowledge (Levy 2017). Therefore, several movements wanted to spread the latest news to become well-informed about the current situation.

The third motivation is related to losing and lack. In the context of loss, it talks about economic and employment issues. As a result, they lost their income, and those who worked in the informal sector, such as online motorcycle taxis and small traders, could not earn income because of this pandemic. Thus, the concern arose to help affected victims. In the context of shortages, it is related to the lack of personal protective equipment for doctors and nurses at the forefront of the COVID-19 examination. 
A total of 32 doctors and 12 nurses have died from COVID 19 infections (Setyowati 2020). Therefore, there were many fundraising actions aimed at health workers and economic victims.

The Indonesian people had taken initiatives based on one core principle or value, based on Pancasila, which was gotong royong. It showed the form of active participation of each individual to give added or a positive value to each object, opposition, or needs of many people around them (Kusumaningrum et al. 2015); however, forming a collaboration does not always have to be formally institutional. It is enough to inform community members about the activity and the timing of its implementation; then, do the work after being finished disband themselves (Irfan 2016). The foundation was the basis for these various online solidarity actions. The emergence of various online movements with this digital platform showed that people ha their way of campaigning for good things. Also, social media were the most effective means today in echoing good action to the community.

It is pretty interesting how significant the role and contribution of technology were to manifest social solidarity movements. Technology had become the infrastructure needed today to drive social solidarity action. Technology became a bridge to connect individuals who cared about each other and united them. Dolata and Schrape (2016) argued that the form of collective behavior outlined originates and develops, as seen, without any conditions. However, the presence of social and technical infrastructure enables the emergence of similarly oriented individual actions and the resulting collective behavior and which coordinates, guiding, monitoring, and, to some extent, controlling such collective activities. The many solidarity movements evidenced this by utilizing access to information and the internet as an instrument to invite many people to move to help others.

Nevertheless, this pandemic situation had the potential to create a kind of solidarity phenomenon, "one-time events." This solidarity phenomenon occurred where social movements that had been institutionalized and had become a trend were used to raise community engagement. It made the movement not virtuous because there were other motives, not purely to help other people. Thus, the community would tend to seek sympathy and support for others. When it was based on pure intentions, the social solidarity movement would automatically get support.

In cyberspace, the potential for hoaxes was even more significant. Considering that the community was experiencing vulnerability due to the paralyzed economy, many broadcasts said that one movement raised donations. For example, a message circulated that the Yogyakarta City Hospital needed a medical device donation and it included an account. However, the message is only fake news solely to take advantage of the situation that occurs. The message was only a hoax to take advantage of this situation. Cyberspace was a lucrative space for spreading hoaxes and stealing public money that was moved by an entity's difficult circumstances.

Nevertheless, massive access to information obtained by the public through the internet was essential in forming a collective attitude. Although the internet had provided a channel for people to mobilize collective action, many types of resources were not easily generated through the internet by ordinary citizens; the examples included socio-organizational resources, trust, and connections with stakeholders (Lee 2015). Internet-based media were aspects of technical infrastructure that made it very easy to echo empathy, solicitation campaigns, and donations. The internet also changed the style of social movements in two ways: 1) by facilitating existing forms of action, making it possible to reach more people, more efficiently, in a period that was not previously thought of, and 2) by creating new tools for activism (Laer \& Aelst 2010).

When the pandemic forced us to go online, an exciting thing to follow was whether Indonesia's technology infrastructures were ready in every part of our territory. With the internet being an essential part of society's culture, the pandemic had re-opened Indonesia's lack of internet infrastructure issues. The social distancing policy had made Indonesian people adapt to the situation. Thus, online activities were the only viable option; however, Indonesia did not prepare to go online. For years, Indonesia had been 
trying to solve technology infrastructure, but the result was less satisfactory. Indonesia's internet user survey results from Indonesian Internet Service Providers Association (Asosiasi Penyelenggara Jasa Internet Indonesia - APJII) in 2019-2020 (Q2) showed a disparity in the internet infrastructure: 55.7\% of internet users resided in Java Island and the rest were Sumatera Island with 21.6\%, Bali and Nusa Tenggara with 5.2\%, Kalimantan with $6.6 \%$, and a combination of Sulawesi-Maluku-Papua with $10.9 \%$. Based on internet penetration on the total population, Java Island had the most considerable number with $41.7 \%$. Next to Java was Sumatera; however, there was a significant percentage difference. Sumatera Island's contribution was only $16.2 \%$. For Bali \& Nusa Tenggara (3.9\%), Kalimantan (4.6\%), Sulawesi (5.1\%), and Maluku-Papua (2.2\%), the percentage did not reach 10\%. Based on this percentage, we can take an early conclusion that there was a digital divide between islands in Indonesia. Thus, much of the online social movements came from Java islands because most of the internet population resided there.

Even though Java Island's internet population was the biggest, there was still a digital divide in Java Island. For example, Oktavianoor's (2020) research which surveyed 100 respondent to examine the digital divide in Agrosari Village, Lumajang, East Java found several interesting things: 1) 64\% of the population were still in the introduction phase, 2) $100 \%$ of the respondents have had smartphone technology devices, however, there were still $31 \%$ of them who were less fortunate and even $17 \%$ were not able to access the internet at all, 3) All respondents' smartphones had Google Chrome web browsing application installed, but only $39 \%$ claimed to be able to operate search engine facilities on the internet, and 4) 51\% of the respondents did not master English, 37\% did not even speak English at all. There was a slight difference when compared to the Wakatobi Regency. The problems faced by the people of the Wakatobi Regency, in general, were the low level of education, low access to information, and the weak level of the community's economy (Hadiyat 2014).

Shaw and Hargittai (2018) described it in their paper where they tested the concept of a pipeline of online participation and model the awareness and behavior necessary to become a contributor using Wikipedia editing as a study case, which stated:

\footnotetext{
"The individuals did not automatically engage in content production on even the most participatory sites, however, they must have the necessary knowledge to do so. The participation divided emerges through a sequence of necessary awareness and behaviors. Education, internet skills, and age had robust associations with outcomes at every step in the pipeline. Other factors, such as income, employment status, and racial or ethnic background, helped explain earlier stages in the pipeline even though they did not associate with who contributed content."
}

This study showed that social movements required colossal participation, and the latter seemed to have many requirements. This is as the case of Argosari Village, Lumajang, East Java that provided evidence that not everyone could get embroiled. They must have digital literacy skills and adequate infrastructures like Internet access and bandwidth.

The social solidarity that was formed during the COVID-19 pandemic was public sympathy for other social groups against the COVID-19 pandemic. Many people were encouraged to remind and help each other who had been affected by the pandemic. Public figures in Indonesia played an important role in generating social solidarity through digital media. Through the role of digital media, this sense of empathy arose that generated a lot of money from donations to be given to poor people, health workers, and patients suffering from Covid-19.

\section{Conclusion}

The pandemic taught us that solidarity was essential to fight the COVID-19 pandemic. With so many sectors being affected, it was only natural for the Indonesian people to work together so that the disasters they were facing will be light; however, this solidarity emanating from the internet did not last long. Moreover, if we look at the people who initiated social movements, most of them were well-known people who had extensive networks and qualified resources. 
In addition, social solidarity had become a tool for others to raise their engagements. Furthermore, with social media speed to spread information, gaining popularity could be pretty straightforward, especially when someone held a social solidarity event. When this phenomenon occurred, there was a shift in social solidarity: from giving to the people into raising an engagement, popularity, and helping people. The movement would not be virtuous. Furthermore, the phenomenon of social solidarity could be used to spread hoaxes. For example, a hoax in the name of Yogyakarta City hospital used people's empathy to get money. In a pandemic situation, this could be dangerous. Society solidarity and empathy became a target for some people to create a hoax and gain benefit.

Nevertheless, with the lack of technology infrastructure in Indonesia, not many people could participate in those movements, especially people from rural areas. There were many challenges to get everyone on the same boat and using the internet smoothly. Unfortunately, the challenge did not only come from infrastructure. There were capabilities and stability that we must consider. In Abraham Maslow's pyramid of hierarchy needs, a social movement is a form of self-actualization because the initiator wants to achieve his full potential as a human being. The rest are joined because they have resources and capability. Those who do not have resources and capability possibly cannot join the movement. It can be shown mainly in material solidarity when the initiators were mostly famous people who had both capability and resources; however, the social movements that emerged during the early pandemic had to be appreciated because they greatly helped the affected communities.

\section{References}

Amindoni A (2020) Virus corona: Pendapatan usaha kecil "pupus" akibat covid 19, pemerintah siapkan bantuan sosial untuk pekerja harian. BBC News Indonesia, 30 March. [Accessed 26 September 2020]. https://www.bbc.com/indonesia/indonesia-52059235.

Annur CM (2020) Hoaks seputar Covid-19 tembus 600, mulai dari Gibran hingga Bansos. Katadata, 27 April. [Accessed 26 September 2020]. https://katadata.co.id/agungjatmiko/ digital/5ea67acb78d10/hoaks-seputar-covid-19-tembus-600-mulai-dari-gibran-hingga-bansos.

Arora G, Kroumpouzos G, Kassir M, Jafferany M, \& Goldust M (2020) Solidarity and transparency against the COVID-19 pandemic. Dermathologic Therapy 13. https://doi.org/10.1111/dth.13359.

APJII (2019) Laporan Survei Internet APJII 2019-2020 (Q2). [Accessed 26 September 2020]. https:// apjii.or.id/survei.

Awalia NI (2020) Transformasi Rachel Vennya dari kecil hingga jadi ibu dua anak. Grid, 24 December. [Accessed 26 September 2020]. https://stylo.grid.id/read/142482799/transformasi-rachelvennya-dari-kecil-hingga-jadi-ibu-dua-anak?page=all.

Bao H, Cao B, Xiong Y, \& Tang W (2020) Digital media's role in the covid-19 pandemic. JMIR mHealth and uHealth 8 (9):1-3.

Bin-Nashwan SA, Al-Daihani M, Abdul-Jabbar H, \& Al-Ttaffi LHA (2020) Social solidarity amid the COVID-19 outbreak: Fundraising campaigns and donors' attitudes. International Journal of Sociology and Social Policy. https://doi.org/10.1108/ijssp-05-2020-0173.

Cheng KK, Lam TH, \& Leung CC (2020) Wearing face masks in the community during the COVID-19 pandemic: Altruism and solidarity. The Lancet. https://doi.org/10.1016/S0140-6736(20)30918-1.

Derung TN (2019) Gotong royong dan Indonesia. Sapa: Jurnal Katektik dan Pastoral 4 (1):5-13.

Dolata U \& Schrape JF (2016) Masses, crowds, communities, movements: Collective action in the internet age. Social Movement Studies 15 (1):1-18. https://doi.org/10.1080/14742837.2015.105 5722.

Elo S \& Kynga H (2007) The qualitative content analysis process. Journal of Advanced Nursing 62 (1):107-115. https://doi.org/10.1111/j.1365-2648.2007.04569.x.

Gunasekaran GH, Gunasekaran SS, Gunasekaran SS, Zaimi N, \& Halim N (2020) Prevalence of facemask use among general public when visiting wet market during Covid-19 pandemic: An observational study. https://doi.org/10.1101/2020.05.17.20105023.

Hadiyat YD (2014) Kesenjangan digital di Indonesia (Studi kasus di Kabupaten Wakatobi). Jurnal Pekommas 17 (2):81-90. 
Ihsanuddin (2020) Fakta lengkap kasus pertama Virus Corona di Indonesia. Kompas, 3 March. [Accessed 26 September 2020]. https://nasional.kompas.com/read/2020/03/03/06314981/fakta-lengkapkasus-pertama-virus-corona-di-indonesia?page=all.

Irfan M (2016) Crowdfunding sebagai pemaknaan energi gotong royong terbarukan. Social Work Jurnal 6 (1):30-42. https://doi.org/10.24198/share.v6i1.13145.

Kitabisa (2020) Selamatkan nyawa Sesama! \#BersamaLawanCorona. [Accessed 24 Agustus 2020]. https://kitabisa.com/campaign/indonesialawancorona.

Krippendorff K (2003) Content Analysis: An Introduction to Its Methodology. California: SAGE.

Kusumaningrum AS, Evi Z, A'yun MQ, \& Fadhilah LN (2015) Gotong royong sebagai jati diri Indonesia. In: Proceeding Seminar Nasional Selamatkan Generasi Bangsa dengan Membentuk Karakter Berbasis Kearifan Lokal, Surakarta.

Laer JV \& Aelst PV (2010) Internet and social movement action Repertoires. Information, Communication \& Society 13 (8):1146-1171. https://doi.org/10.1080/13691181003628307.

Lauer AS, Grantz KH, Bi Q, Jones FK, Zheng Q, \& Lessler J (2020) The incubation period of coronavirus disease 2019 (COVID-19) from publicly reported confirmed cases: Estimation and application. Annals of Internal Medicine 172:577-582. https://doi.org/10.7326/M20-0504.

Lee FL (2015) Internet, citizen self-mobilization, and social movement organizations in environmental collective action campaigns: Two Hong Kong cases. Environmental Politics 2 (5):308-325. https://doi.org/10.1080/09644016.2014.919749.

Levy N (2017) The bad news about fake news. Social Epistemology Review and Reply Collective 6 (8):20-36.

MacNamara J (2005) Media content analysis: Its uses, benefits and best practice methodology. Asia Pacific Public Relations Journal 6 (1):1-34.

Meinzen-Dick R (2020) Collective action and "social distancing" in COVID-19 response. Agriculture and Human Value 37:649-650.

Oktavianoor R (2020) Kesenjangan digital akibat kondisi demografis di kalangan masyarakat rural. Palimpsest: Journal of Information and Library Science 11 (1):9-19. https://doi.org/10.20473/ pjil.v11i1.21888.

Priliantini A \& Damayanti (2018) Peran media sosial "Facebook" dalam membentuk solidaritas kelompok pada aksi 411 dan 212. Jurnal Komunikasi, Media dan Informatika 7 (1):37-48. https:// doi.org/10.31504/komunika.v7i1.1359.

Sembiring LJ (2020) 1,5 Juta masyarakat RI kehilangan pekerjaan karena COVID-19. CNBC Indonesia, 11 April. [Accessed 26 September 2020]. https://www.cnbcindonesia.com/ news/202004112130434-151261/15-juta-masyarakat-ri-kehilangan-pekerjaan-karena-covid-19.

Shaw A \& Hargittai E (2018) The pipeline of online participation inequalities: The case of Wikipedia editing. Journal of Communication 68 (1):143-168. https://doi.org/10.1093/joc/jqx003.

Setiawan R (2020) Saat pemerintah lambat, rakyat bersolidaritas hadapi COVID-19. Tirto, 25 March. [Accessed 26 September 2020]. https://tirto.id/saat-pemerintah-lambat-rakyat-bersolidaritashadapi-COVID-19-eHIS.

Setyowati D (2020) 44 dokter dan perawat RI meninggal dunia akibat Virus Corona. Katadata, 12 April. [Accessed 2 May 2020]. https://katadata.co.id/berita/2020/04/12/44-dokter-dan-perawatri-meninggal-dunia-akibat-virus-corona.

Smythe S, Wilbur A, \& Hunter E (2021) Inventive pedagogies and social solidarity: The work of community-based adult educators during COVID-19 in British Columbia, Canada. International Review of Education. https://doi.org/10.1007/s11159-021-09882-1.

Stewart M \& Schultze U (2019) Producing solidarity in social media activism: The case of My Stealthy Freedom. Information and Organization. https://doi.org/10.1016/j.infoandorg.2019.04.003.

Szczesniak D, Ciulkowicz M, Maciaszek J, Misiak B, \& Rymaszewska J (2020) Psychopathological responses and face mask restrictions during the COVID-19 outbreak: Results from a nationwide survey. Brain, Behavior, and Immunity 87:161-162. https:doi.org/10.1016/j.bbi.2020.05.027.

Thijssen P (2012) From mechanical to organic solidarity, and back: With Honneth beyond Durkheim. European Journal of Social Theory 15 (2012):454-470. 
Valeriani G, Sarajlic Vukovic I, Lindegaard T, Felizia R, Mollica R, \& Andersson G (2020) Addressing healthcare gaps in Sweden during the Covid-19 outbreak: On community outreach and empowering ethnic minority groups in a digitalized context. Healthcare 8 (4):445. https://doi.org/10.3390/ healthcare 8040445.

Vennya R (2020) Tolong menolong lawan COVID-19. Kitabisa, 16 March. [Accessed 26 March 2020]. https://kitabisa.com/campaign/bersamacegahcovid19.

Wamboldt RN (1992) Content analysis: Method, application, and issues. Health Care for Women International 13 (3):313-321. https://doi.org/10.1080/07399339209516006.

Zahri TA, Lubis PH, \& Ahrom S (2019) Relasi pemuda Islam dan media sosial dalam membangun solidaritas sosial. Jurnal Literasiologi 1 (2):1-13. 